\title{
The Goldwater Phenomenon: Purists, Politicians, and the Two-Party System
}

\section{Aaron Wildarsky}

7 HE Goldwater phenomenon is the great mystery of American politics. His nomination as presidential candidate by the Republican Party and his campaign for election have profoundly challenged accepted theories of American politics. Merely to enumerate some of the puzzling questions suggests how badly we need explanations.

How was it possible for a presidential nomination to go to a staunch conservative whose popularity among the electorate was known to be exceedingly low and who was far from being the preferred choice of most Republican voters? Why, in a competitive two-party system in which leaders normally seek essentially the same votes, did the parties seem to be hurtling further apart instead of coming closer together? Why, indeed, did not the minority party (the Republicans) imitate the majority party (the Democrats) in search of votes as had previously been the case? Why did the Goldwater Republicans not follow the traditional practice of "balancing the ticket" by choosing a more liberal person as their vice-presidential candidate? Why did Goldwater and his followers put such great stress on consistency and yet appear so inconsistent in their pronouncements? Since Goldwater said that the race question should not become an issue in the campaign, why did he refuse to take the steps which would have helped accomplish that end - voting for the Civil Rights Act of 1964, and making some conciliatory statement to Negroes? Why did Goldwater slant his appeal to working-class people and Johnson to middle- and upper-class voters in an apparent shift from the usual tendencies in electioneering? Since the candidates were further apart on issues than at any time in recent decades, why was there so littlc discussion of issues and so much talk about personalities in the campaign?

To put the questions in this way suggests that we are surprised; that our expectations concerning the behavior of parties and politicians have been violated. Ordinarily, we expect both major parties to choose popular candidates with a good chance of winning. The death wish is not supposed to be dominant among poli- 
ticians. Party leaders are expected to conciliate groups of voters in order to get at least part of their vote. Abandoning a large number of citizens to the enemy is not usually done. The vice-presidential nominee is usually chosen, as were Lyndon Johnson and Henry Cabot Lodge in 1960, to broaden (not further to restrict) the appeal of the party. And the major parties often accommodate themselves to the most popular part of the opposition's policies in order to enhance their prospects of victory. Yet none of these things happened - at least on the Republican side - in 1964. Why?

In order to answer these questions, I shall try to define the character of the Goldwater movement and to relate it to the traditional practices of American political life. I shall begin with an explanation of why Goldwater won the nomination, go on to an examination of his special political style, and end by drawing out the implications of this analysis for the future of the two-party system.*

* Since my conclusions may appear controversial, I shall indicate the major sources of the statements used here. Those concerning the normal operations of the party system are adapted from such standard works as Pendelton Herring, The Politics of Democracy; Austin Ranney and Wilmoore Kendall, Democracy and the American Party System; V. O. Key, Politics, Parties and Pressure Groups, and Robert Dahl, Preface to Democratic Theory. The material on the goals of convention delegates comes from Nelson Polsby and Aaron Wildavsky, Presidential Elections. Generalizations on voting behavior are drawn primarily from Campbell, Converse, Miller, and Stokes, The American Voter. I have also relied heavily on the only systematic work comparing convention delegates and ordinary voters-Herbert McClosky et al., "Issue Conflict and Consensus Among Party Leaders and Followers," The American Political Science Review, LIV (June, 1960), 406-27. (See also McClosky's "Consensus and Ideology in American Politics," American Political Science Review, LVIII (June, 1964), 361-82).

After the 1956 conventions, McClosky distributed, and then analyzed, lengthy questionnaires filled out by large numbers of Republican and Democratic delegates and by samples of voters who identified with these parties. Using McClosky's work, one can make reliable statements about the characteristics and issue preferences of party leaders (represented at the conventions) and party followers (as they are found throughout the nation). Finally, I have made substantial use of some 150 interviews with Goldwater delegates held at the Hotel Fairmont in San Francisco, where the California, Illinois, and New Jersey delegates were housed. The interviews were conducted in the hotel lobby by myself, my sister, Judy Gordon, a friend, Maralyn Millman, and two graduate students - James Payne and Joseph Paff. Gerry Bass helped by monitoring the press for us. While these unstructured, probing interviews in no way represent a systematic sample of the delegates, they were undertaken because they have one great advantage over the usual mail questionnaire: the interviewer can try to insist on answers and pound away until some kind of response is forthcoming. 


\section{Delegates Are Different}

The convention delegates of the Democratic and Republican Parties are elite groups of political activists. While these party leaders undoubtedly share many of the characteristics of their followers among ordinary voters, they also differ from them in significant ways. The leaders are much more interested in public affairs and active in trying to do something about them. They know more about the public issues and care more about them. They are more highly educated. Some 60 percent of the leaders have held public office at one time or another, and the same proportion occupies a party position, usually at the county level. Their identification with and commitment to their political party are much stronger than that of ordinary citizens and voters.

Knowing and caring more about issues and the sort of connections between them, and intensely committed to a partisan stance, Republican and Democratic leaders hold more consistent views on more issues than do their followers. There are sharp, clear, and wide differences between Democratic and Republican leaders on many important issues, and hence policy preferences. Public housing and urban renewal, medical care for the aged, aid to education, reliance on the United Nations, foreign aid, and participation in military alliances are just a few of the issues on which meaningful differences appear. Their followers, however, are much closer together. They differ only moderately from one another along gentle liberal and conservative lines; they do not reflect the wide divisions among party leaders. Furthermore, leaders are far more likely than followers are, to believe that the major parties should hold sharply different views on issues. While some 50 percent of the leaders favor wide differences between the parties, only 20 percent of the followers share this view. Thus the persistent belief that party voters demand sizeable policy differences between the parties and are thwarted by calculating politicians who do not care about issues is wrong. If party leaders neglect or blur differences on issues this results not from following their own preferences, but from subordinating them in deference to the electorate.

Do leaders differ from followers? Republican leaders disagree rather strongly with their followers among the voters on a wide range of issues. Indeed, Republican followers are closer to the Democratic rather than Republican leaders on issue preferences. While there are disagreements between Democratic leaders and 
followers, these are less pronounced and occur less often. After determining the support ratios for leaders and followers on 24 domestic and foreign policy issues, McClosky concluded:

Consideration of the scores of Republican leaders and followers shows not only that they are widely separated in their outlooks but also that the leaders are uniformly more conservative than their followers. . . . The largest differences occur on those issues which have most sharply separated New Deal-Fair Deal spokesmen from the hard core of the Republican opposition - federal aid to education, redistribution of wealth through taxes on business corporations and the wealthy, public ownership of natural resources, public housing, regulation of business, social security, farm price supports, minimum wages, and trade union regulations. 1

This gives part of the explanation we are seeking. Delegates at the Republican convention may nominate a conservative who is popular neither with the electorate as a whole nor with their own voters because the leaders of the party are much more conservative than their followers. These are, of course, general tendencies, for there are leaders more liberal and followers more conservative than these groups as a whole. Yet the central tendency for divergence between most leaders and most followers is clear and beyond dispute. If this is the case - and it has probably been true since the New Deal period - why did the Republican Party, from the 1930's to 1964, fail to nominate an avowed conservative whose policy preferences would more nearly coincide with the views of most of its leaders? Clearly, most Republican leaders have subordinated their personal preferences for a more conservative candidate in favor of other goals. It is worth exploring, then, the goals of party leaders (at least before 1964) as they have been determined in a competitive, two-party system.

\section{The Goals of Delegates}

Delegates to the national conventions may have motives which are personally their own: fame, glory, compensation for personal defects, the desire to manipulate others, the wish to be of service, the love of human drama; the possibilities are endless. Fortunately, it is not necessary to play psychoanalyst to understand their behavior. Delegates are party activists. When they come to the convention they enter into a social system in which their roles

IThe American Political Science Review, LIV (June, 1960), 423. 
and expectations are defined with some clarity. What counts for us is not their individual personalities, but their collective goals as party leaders in a two-party system which limits and guides their behavior.

American national parties are loose federations of independent state parties, representing somewhat different combinations of ethnic, religious, sectional, economic, and other interests. What holds them together (particularly those who do not share the prevailing ideology) is the hope of forming a coalition sufficiently broad and inclusive to win the greatest office in the land - the presidency. In order to accomplish this goal the parties seek to appeal to as many different people as possible. They must broaden their appeal even if this means neglecting some issues, watering down others, and reconciling divergent interests as best they can. It is not surprising, therefore, that the first goal of the delegates may be to find "The Man Who Can Win," for without hope of victory over the years it would be difficult for the party to stay together. A party which cared more about maintaining its ideological purity than about winning would lose all hope of gaining public office and affecting public policy.

It is possible to describe briefly the major goals of most delegates to national conventions: they want not only to nominate a man who can win the election but also to gain power, to unify the party, to obtain a claim on the nominee, to strengthen their state party organization, and to protect their central core of policy preferences insofar as this is consistent with their other goals. Despite the fact that most Republicans hold conservative opinions and would prefer a candidate who shares them, they have, in the past, given primacy to their other goals in order to have a chance of winning in a competitive, two-party system. Yet if the goal of winning the election predominated, as it had in the past, the Republican Party would have been unlikely to nominate Goldwater. The next step, then, is to explain how political circumstances operated to decrease the relevance of this goal and to bring others into prominence.

\section{Special Political Conditions}

By far the most important special condition of 1964 was that for the first time in 30 years there was no moderate Republican candidate who was both popular with the voters and willing to 
contest the nomination actively. Whatever the reasons, Nelson Rockefeller simply did not appeal to voters in Republican primaries. Henry Cabot Lodge would not campaign and go on the ballot in California. Richard Nixon had ruled out an active public role for himself. And Governor Scranton could not or would not overcome his reluctance to seek the nomination until it was too late. It is difficult to stop something with nothing, as Goldwater's opponents learned to their sorrow.

Participation in presidential primaries is usually the preferred strategy of aspirants who cannot be chosen by compromise at the national conventions. Men like Kennedy and Humphrey in 1960 or Goldwater and Rockefeller in 1964 actively contest many primaries because they have to establish overwhelming support before the conventions meet in order to have a chance. Candidates like Nixon, Lodge, and Scranton, however, may reasonably hope to be the choice of the convention after the front-runners have demonstrated that they cannot win. So they stay out of primaries and wait to pick up the pieces. This strategy proved disastrous in 1964 because Nelson Rockefeller was unexpectedly unable to play the role allotted to him; he failed to defeat Goldwater in the California primary and the contest was over before it was supposed to have started.

Another significant condition involved the almost universal expectation that no Republican candidate had a chance of beating Lyndon Johnson. This belief vastly reduced the persuasiveness of the usual argument that the Republican Party should put up a popular candidate who might win. Goldwater's opponents had to content themselves with the much weaker argument that another candidate would lose by less.

A strong case might still have been made that the fortunes of Republicans running for state and congressional offices would be improved, or at least not seriously impaired, by running a more popular candidate for the presidency. But this argument was weak in some respects. Republicans from the South and portions of the West and Southwest contended that Goldwater would run as well as, if not better than, any other Republican. And some Republicans were so intensely committed to a conservative victory at the convention, and so frustrated at their previous inability to win the nomination, that they convinced themselves that a "hidden conservative vote" would emerge to help them at the state level. 
There were state leaders who winced at the thought of a disastrous defeat in November. But there were fewer such leaders than there might have been precisely because the Republicans are a minority party. There were only 17 Republican state governors at the Republican Convention. These were the men who might have had sufficient hierarchical control over their delegations to keep them from precipitantly joining the Goldwater bandwagon. In the absence of such central leadership, the tendency of most delegates to favor a highly conservative candidate had greater scope to manifest itself.

One might suppose that when the goal of nominating a winner could not be met, some of the delegates would have put a premium on the goal of party unity. To be sure, there was less urgency in achieving unity because victory in the election was not expected anyhow. But if defeat seemed to be inevitable, delegates who cared about the Republican Party as an organization might have hoped at least to salvage unity. Goldwater had the advantage here because he could work to unify the party around him. Since he had the lead, his backers could claim that the great danger to party unity lay in stubborn refusal to accept him.

Again, the belief that the Republican Party was bound to lose the election not only reduced the need to nominate a popular candidate, but also opened up the possibility of using the conflict over the nomination as a means of gaining control of the various state parties. The leaders still cared about winning, but their notion of the relevant contest changed. Wherever Goldwater had strong support among Republican activists, opposing party factions could be beaten down in the name of support for him. Had there been a popular candidate to oppose Goldwater, the opposition might have elected to fight the battle around this champion. In the circumstances, however, they were faced in many states with the choice of going down to defeat or nominally accepting Goldwater. Some Republican leaders, as was apparently the case with Charles Percy in Illinois, decided to try to maintain their influence within the party by rolling with the Goldwater tide and thus living to fight another day. This is precisely what Governor DiSalle of Ohio did in 1960 when a hostile faction of the Democratic Party threatened to use John F. Kennedy's popularity as a club with which to beat him. By supporting Kennedy, he was able to defeat his opponents within the party. 
Although its effects are difficult to determine, a third contemporary condition must also be mentioned. The impact of the civil rights issue had given rise to hopes that, for the first time since the unsuccessful presidential campaigns of William Jennings Bryan (1896, 1900, 1908), a party might win by carrying a coalition of southern and western states. The attraction of such a coalition was that it made a conservative candidate more plausible by removing the necessity to appeal on the basis of welfare issues to the labor and minority groups in the populous industrial states. These carry so much weight in the electoral college that the Republican Party has had to appeal to them in the past through moderate candidates and platforms.

Yet even if Goldwater's supporters could convince themselves that his cause was not utterly hopeless, the very fact that they chose him suggests that winning the election was not uppermost in their minds. Politicians have been accused of many things; up till now no one has accused them of wishing to lose elections. Has the United States, then, given birth to a new kind of political activist for whom other things rank above winning office? Interviews held with Goldwater delegates to the Republican Convention may help to answer this question.

\section{Purists vs. Politicians}

"The delegates are for Goldwater because they agree with his philosophy of government. That's what you people will never understand - we're committed to his whole approach." This Goldwater delegate was undoubtedly correct. There was a remarkable fit between Goldwater and a substantial majority (approximately 80 percent) of his followers. What they liked about Goldwater, however, was not merely or even primarily his policy positions but rather his "approach," his style of operation. When we asked Goldwater delegates to tell us what they most liked about their candidate only a few mentioned his position on the issues, and those who did were content with brief references to constitutional principles like states' rights.

By far the most frequent characterizations of Goldwater referred to his consistency, honesty, integrity, and willingness to stick by principles. It was not so much his principles (though these were undoubtedly important) but the belief that he stuck to them that counted most with his supporters. "He can be trusted." "He is 
straightforward." "He does not compromise." "He doesn't pander to the public; he's against expediency." "He is frank." "He has courage." "He stands up for what he believes." "He won't play footsie with the people." "He votes his convictions when he knows he's right." "He doesn't go along with the crowd." "He meets issues head-on." "Goldwater speaks about things others avoid. Most politicians like to avoid issues." "He keeps promises." "He doesn't change his mind." "He is not confused." As one of Goldwater's supporters perceptively observed, "He's different than most politicians." And so are most of Goldwater's followers "different than most politicians."

It thus becomes possible to divide delegates into "politicians" and "purists" according to their characteristic modes of approaching political life. While not all Goldwater supporters were purists (some 20 percent were politicians), all purists were Goldwater supporters.

In order to derive typologies of politicians and purists, let us observe the "pure" types as they were revealed through interviews at the Republican Convention. This Goldwater purist was a delegate from a rural area in Pennsylvania attending his first convention.

Interviewer: What qualities should a presidential candidate have?

Delegate: Moral integrity.

I.: Should he be able to win the election?

D.: No; principles are more important. I would rather be one against 20,000 and believe I was right. That's what I admire about Goldwater. He's like that.

I.: Are most politicians like that?

D.: No, unfortunately.

I.: What do you like about Goldwater?

D.: I am in sympathy with many of his philosophies of government, but I like him personally for his moral integrity. I always believed that a candidate should carry out his promises. Scranton didn't do that. But now, for the first time in my life, we have a candidate who acts as he believes. He doesn't change his position when it is expedient.

I.: Do you think that if the party loses badly in November it ought to change its principles? 
D.: No. I'm willing to fight for these principles for ten years if we don't win.

I.: For 50 years?

D.: Even 50 years.

I.: Do you think it's better to compromise a little to win than to lose and not compromise?

D.: I had this problem in my district. After we fighters had won [the nomination for] the congressional seat the local [Republican] machine offered to make a deal: they wouldn't oppose our candidate if we didn't oppose theirs. I refused because I didn't see how I could make a deal with the men I'd been opposing two years ago for the things they did. So I lost and I could have won easily. I've thought about it many times, because if I had agreed I could have done some good at least. But I don't believe that I should compromise one inch from what I believe deep down inside.

Here we begin to see the distinguishing characteristics of the purists: their emphasis on internal criteria for decision, on what they believe "deep down inside"; their rejection of compromise; their lack of orientation toward winning; their stress on the style and purity of decision - integrity, consistency, adherence to internal norms.

The professionals look at politics quite differently. Here is a California delegate strongly for Goldwater, with more than 15 years in party work, attending his third Republican convention.

Interviewer: You seem different from many of the Goldwater supporters. How would you characterize your position in comparison with them?

Delegate: Yes, I'm more practical. I realize you have to live together. For example, I'm going up now to a meeting of the California Republican committee and we've got to handle a liberal candidate and an ultra-conservative. I'm going to urge them to accept the liberal because we've got to work together. We [the Republicans] are a minority party in California and we can't afford to squabble amongst ourselves. The art of politics is the art of compromise. If I can get a whole loaf, I'll take it. If not, I'll take half rather than lose it all.

I.: What would Goldwater do about the Cuban situation? 
D.: Well, it's there now and we'll just have to live with it.

I.: The Berlin Wall?

D.: He won't tear it down; I know him very well.

I.: Social Security?

D.: We've had it for a long time, it's part of our system. That's something some of these Goldwater people don't realize. They're a new breed and sort of naive on things like this. They think you can suddenly shift the whole range of government to the right. What they don't realize is that you can only bend a little back away from the left.

I.: What if Goldwater loses by a landslide?

D.: Well, I don't think that will happen.

I.: Suppose it does?

D.: Well, then, maybe the people aren't ready for a change. ... Yes, we'll have to try to change, maybe a little more toward the liberal side.

The belief in compromise and bargaining; the sense that public policy is made in small steps rather than big leaps; the concern with conciliating the opposition and broadening public appeal; and the willingness to bend a little to capture public support are all characteristics of the traditional politician in the United States.

Having sketched some of the essential attributes of purists and politicians, we can proceed to a closer examination of these two types, with special emphasis on the purists.

\section{Winning Elections}

"I've talked to some of the California delegates," a citizen who observed the convention informed us, "and I don't understand them at all; they talk like they don't care if we win." In a sense he was wrong, because the delegates desperately wanted Goldwater to win. But our informant was essentially correct in the sense that they cared more about maintaining their purity "I would rather lose and be right" - than about winning. The essential element of this style was a devotion to principles especially the principle that they should have, maintain, and cherish their principles.

When asked why they entered politics, Goldwater delegates often answered, "For the same reason as any man: principles." When asked if the party should change some of its policies if Gold- 
water lost badly, the delegates responded by reiterating their devotion to principles. "God, no. These are American principles; these are what we stand for." "No, we want a clear party which will represent principles to the people." "I'd rather stick by the real principles this country was built on than win. Popularity isn't important; prestige isn't important; it's the principles that matter."

Although the politicians put a high premium on popularity with the electorate, there were things they would not do and ways they would not prefer to win. A Scranton delegate, in politics for many years in Philadelphia, pointed out that in his white, upper-class ward he and his party had benefited from a "white backlash" issue in a local election. "But we don't want that; that divides the country. We don't want whites and blacks to fight: it's not good for the country." A New Jersey delegate with many years of political experience did not really like any of the candidates for the nomination and feared that the party would fare badly at the polls if Goldwater were nominated. Yet he felt that things could happen: "a white backlash building up if the Negroes have a lot of big demonstrations in the cities; or if Viet Nam blew up in our faces. But I'd rather lose than have those things happen. I'd rather lose than have race fights or war."

One great difference between the purists and the politicians lay in what they would consider grounds for preferring not to win. The politicians emphasized specific unfortunate consequences for people in the country such as race riots and war. The purists emphasized departures from internal principles held by their party leaders such as consistency, integrity, and standing firm. The politicians were oriented toward what happens to other people, the purists toward their individual consciences.

\section{Emphasizing Differences}

An important component of the Goldwater style was the guiding principle that the parties ought to be different. The maintenance of wide and sharp differences between the parties was seen as a fundamental purpose of engaging in politics. As an enthusiastic woman delegate from New Jersey put it "I think everything should be an issue, civil rights should be an issue, Cuba should be an issue. This is the first time a campaign will be on issues; I think it's wonderful. It's just terrible the way personality has been in politics, like Kennedy winning on his hair and teeth 
and Nixon losing because there was a shadow on his chin ... it's ridiculous."

Hence when Goldwater supporters were asked whether they should balance the ticket with a liberal vice-presidential candidate, they replied: "We don't want a blurred image, we've been a metoo party for too long. We want to take a clear position." If, in order to provide clear differences between the parties, the Republicans lose, that is all right. For "even if the party loses at least we have presented a clear alternative to the people. At least we'll have a strong party." What is meant by strong? "Cohesive, united on principles." The chorus of Goldwater purists rose to a crescendo when they insisted, in almost identical words, "We don't want to become a me-too party, we don't want to be the same as the Democrats." The possibility arose, therefore, that if they were offered accommodations or compromises on issues they would reject them because they wanted to be different.

The ideal party of the purists is not merely a conservative party; it is also a distinct and separate community of co-believers who differ with the opposition party all down the line. To this extent their style merges with that of the liberal party reformers, described by James Wilson in The Amateur Democrat, who wish to see the parties represent clear and opposed alternatives and gain votes only through appeals on policy difference rather than on such "irrational" criteria as personality, party identification, or ethnic status. But the Goldwater purists went even further in their willingness to cast aside whole groups of voters who did not agree with them. "We won't get Negro votes anyway, so there's no point in trying." "They can vote for the other party for all I care." "We won't change our principles just to get a few votes from Negroes." In the same spirit, Barry Goldwater suggested that people who favored the kind of government the United States has had since 1932 should vote not for him but for his opponents.

For the politicians, the desire to win is intimately connected with the belief that a political party should try to get as much support from as many diverse groups as possible. In describing the qualities a presidential candidate should have, a professional will say, "He should be diplomatic. He should be able to gather support from a lot of groups underneath him. That's what Eisenhower had, that's what Kennedy had, and that's what Johnson has. You know there's one thing about politics, there's no such 
thing as second place, you don't get anything for coming in second."

Hence the professionals were concerned with losing a substantial part of the small Negro vote they had received in the past. "You just can't go around throwing away votes. The object of a party is to draw voters together to the party, not to push them away." A delegate from Philadelphia was more specific. He had "nothing personal against Goldwater" but feared that if he were to run "we'll get the hell kicked out of us. We've been out of [state] power for ten or 12 years. Now we're getting some of the Polish vote and the Italians don't treat us too bad. The Jews and the Negroes go about 75 percent against us, but at least we get part of the Negro vote and that helps us hold the line in the state generally."

To their dichotomous view of political parties and their belief that issue preferences were the only moral way to choose between them, the purists added a strong desire to simplify political choice: a party for the growth of government and a party against; a party which believes in standing up to the enemy and one which believes in appeasement; a party which believes in private initiative and one which wishes to stifle it; the party of free enterprise versus the party of socialism.

The desire to dichotomize and simplify found expression in ways of locating political supporters and opponents. Perhaps the most charming example came from a California delegate who expressed the wish to see all liberals in the East and all conservatives in the West. Presumably, if one knew where a man came from, one could immediately discern his political tendency. Many delegates voiced the desire to divide friend from foe by simple criteria and then do joyous battle.

\section{The "Privatization" of Politics}

We may sum up the Goldwater style by saying that it represented a virtually complete privatization of politics. The private conscience of the leader rather than his public responsibilities became the focal point of politics. Internal criteria - possession of, devotion to, standing up for private principles - became the standard of political judgment. This is far from Burke's principle that the representative be allowed to use his own judgment about what course of action will bring the greatest benefit to his con- 
stituents. Rather, the constituents disappear, and we are left with a political leader determining policy on the basis of compatibility with his private principles.

From this perspective we can better understand why Goldwater voted against the Civil Rights Act of 1964 despite his agreeing with the view that the race issue should not become a matter of political partisanship. Goldwater's conscience dictated that he vote against an act which contained two sections he felt violated the Constitution. Although he knew that the act would pass anyway, he was simply unwilling to sacrifice his private conscience in order to achieve what he agreed was the public good. Goldwater undoubtedly believed that adherence to the Constitution was also part of the public interest. The point is that when faced with competing conceptions of public good, he chose a remote abstraction over a direct and specific human value. Nor would he or his supporters agree to make rather innocuous concessions on the civil rights plank in order to placate Negroes because that would have suggested compromise; and compromise suggests that one has not stuck to one's principles.

Once the platform became identified as a Goldwater platform, presumably derived from careful scrutiny of conscience, it became a matter of principle not to permit any alteration whatsoever, even if this meant alienating other party factions on the extremism issue. The very idea that the Republican Party should try to balance its ticket with a less conservative vice-presidential candidate was uniformly regarded as immoral and despicable. Such thoughts reeked of inconsistency, me-tooism, expediency, and other political vices stemming from the lack of conscience in politics.

Conspicuously missing from purist thought was consideration of voters. Party was defined entirely without reference to the people who would have to vote for it. True, the purists believed that there was a "hidden Republican vote," and they fully expected a huge upsurge of support as most Americans discovered that a party embracing their most cherished principles had at last appeared on the scene. But the "real Republican Party," as they were fond of calling it, was far removed from vulgar pandering for votes. It stood on its principles. It did not change to attract votes. Voters were attracted to it when people changed.

One can see the privatization of politics at work when Goldwater delegates expressed their feelings about President Johnson 
and former President Eisenhower. Extremely hostile feelings were expressed about both men because they were seen as traditional politicians gifted in the arts of compromise. Goldwater's castigation of Johnson as a "faker," for example, was uniformly regarded as accurate and appropriate. "Originally and historically," a delegate told us, "Johnson was a conservative, but he's willing to do things, to change to stay in power. This shows weakness of character."

The purists did not think it appropriate that a Senator on becoming President should act differently. If a public official need consult only his private conscience, of course, there should be little change in his actions in different offices. If Johnson acted differently in the two offices this could only be because "he has no principles. L.B.J. is a consummate politician. He is inconsistent and immoral." Goldwater was different. "He doesn't talk from both sides of his mouth."

If the essence of politics is to be found in the relationship between leaders and their principles, one would ask quite different questions and give much different answers to queries about the positions taken by candidates. When we asked delegates about Goldwater's position on racial matters, the purists would always respond by saying that Goldwater himself was not bigoted. They knew the exact percentage of employees in the Goldwater department store in Phoenix who were non-Caucasians. They pointed with pride to this statistic as evidence of their candidate's favorable disposition toward Negroes. There was no mention of what Goldwater might do as President; there was no understanding that the public role of a Presidential aspirant might be of interest. Negro delegates, to be sure, could not have cared less about Goldwater's personal predilections. They wanted to know what he would do for Negroes in his capacity as President of the United States. That Goldwater shared this perspective became evident during the campaign when he asked if Negroes would not rather have a President who dealt with race relations as a matter of conscience instead of as a political football. Since political action is a major method of redressing Negro grievances, it is not surprising that Goldwater failed to get his conscience accepted as a substitute for favorable presidential action.

The privatization of politics leads to an a priori approach to politics. Problems are met by stating one's first principles and 
assuming that they must be relevant to whatever is in hand. One gets no sense whatsoever that Goldwater purists approached problems by inquiring how special circumstances might be taken into account in order to achieve desirable results. The pragmatic spirit was completely lacking. Indeed, the purists manifested amazingly little interest in specific issues. In our interviews at the convention, we simply could not get them to talk about anything concrete, unless references to welfare-statism and too-much-government are considered specific replies. The purists did express strong belief in the importance of being interested in issues, but this is not equivalent to being interested in specific issues.

All this makes one wonder whether the Goldwater phenomenon did not represent a retreat from politics through politics. Purists are interested in being interested in politics. They care about people caring about politics. They are far more concerned about the need for substantial differences between the parties than they are about the differences themselves. If only one has principles and stands up for them, their position seems to suggest, the messy world of politics - compromise, bargaining, exceptions, modifications, inconsistencies - will disappear. Political style thus becomes a substitute for politics itself.

\section{Campaign Style}

The campaign speeches of Barry Goldwater are a testimonial to the extraordinary importance he assigned to political style. It would be difficult to find another candidate so insistent that people not vote for him if they did not share his views. Rarely has so much attention been given to stylistic reasons for supporting a candidate. This approach is epitomized in a Goldwater speech delivered to a rally at Madison Square Garden and its overwhelming stylistic emphasis is noteworthy.

Goldwater began by saying that although he knew what statements would get him the most votes he was not going to make them.

I can't help wondering sometimes, if you've asked yourselves why my campaign is what it is.

I wonder, my fellow Americans, if you think I don't know what views would be most popular. Do you think I don't know what labor wants to hear, what management ... what housewives and diplomats and white-collar workers want to hear? 
Do you honestly think, after all these years in politics, that I don't know the easy ways to get votes? The promises to make? The subjects to talk about - and the ones to avoid? Well, I do!

He then proceeded to tell his audience why he did not "take the easy way."

First of all, if I just went around telling people what they want to hear, I'd sound like Lyndon Baines Johnson. And I still think the American people are entitled to a choice.

But more important, if I had to cater to every special interest in the country to get elected, I wouldn't want the job.

Like his followers, Goldwater was a political purist who objected to telling people what they wanted to hear, catering to "special interests," or being like the other party in order to gain popularity.

As a political purist, Goldwater was careful about the kind of people who should and should not support him. The Nazi and Fascist types, the Communists and left-wing radicals, were clearly beyond the pale. But Goldwater included "The lazy, dole-happy people who want to feed on the fruits of somebody else's labor" and people who believed in promises and those "who are willing to believe that Communism can be 'accommodated." " Most revealing, for our purposes, was his characterization of the people he believed would vote for him.

People who take the trouble to reread, thoughtfully, the Declaration of Independence and the Constitution of the United States will vote for me. ...

People who have learned to be suspicious of never-ending promises of "something for nothing" - they will vote for me.

People who have the courage and the intelligence to listen to the truth, and think about it. People whose votes can't be bought. They'll vote for me.

People who are sick to death of politicians coming out in favor of happiness and declaring war on misery. People who are fed up with so-called leaders of government promising to legislate worry out of existence. People who will listen for a little while to such transparent, vote-grabbing demagoguery and say - " $\mathrm{Ba}$ loney." They'll vote for me.

But most of all, it will be the people who know that something must be done.2

${ }^{2}$ New York Times, October 27, 1964. 
The types of people who Goldwater thought would vote for him were stylists. They were not merely people who agreed with Goldwater on specific issues. Rather, they were people who harked back to basic principles, such as may be found in the nation's venerable documents, people who were suspicious of promises, who had courage, who were "sick to death of politicians," and who knew that something must be done.

\section{Campaign Strategies}

Fought between a political purist and a traditional politician, the 1964 election campaign was most peculiar by recent American standards. The parties appeared to slant their appeals somewhat differently from past emphases. The Democrats appealed much more to upper-income groups and the Republicans to lower-income groups than was usually the case. Despite (or perhaps because of) the larger differences in positions on issues, questions of personality and morality - was Goldwater irresponsible or Johnson a crook? - seemed to dominate the campaign. For the first time in many years, the Republicans made more appeals based on party identification than did the Democrats. And the candidate who put so much weight on consistency appeared to his opponents at least to be a most inconsistent man. Beginning with a brief discussion of the usual pattern of campaign strategies, we shall use our analysis of the Goldwater style and the specific context of the time in an effort to provide a coherent explanation of these apparent anomalies.

Holding the allegiance of approximately three out of every five voters, the Democratic Party can expect to win any election which is determined on the basis of party preference. As a result, Democratic candidates typically stress their party identification, while Republican candidates play it down. In 1964, however, the fact that Senator Goldwater was so far to the right of most Republican voters gave President Johnson the opportunity to detach a significant portion of that party's traditional supporters. In search of this Republican vote, Johnson eschewed the usual partisan appeals. Instead, he went out of his way to praise the good old Republican Party of yesteryear and to ask the electorate to reject the unnamed extremists who had temporarily taken control of it. While maintaining his party's historic position on welfare issues, 
Johnson carefully toned down his comments so as not to give moderate Republicans an excuse for voting against him. If he could not positively attract Republicans, he would do nothing to repel them. So the President adopted the stance of national unity, calling insistently on Americans to get together against certain demagogues and hotheads who might get the United States into a nuclear war or foment racial strife.

So far as domestic welfare policies were concerned, there was overwhelming evidence that the vast majority of voters were far closer to the liberal Democrats than they were to the most conservative Republicans. Hence Democratic candidates traditionally hit hard on "bread and butter" issues, while Republicans were caught in a dilemma: they could not please their conservative party activists and the voters at the same time. Since there are many more voters than activists, Republican candidates have normally chosen to go along with most welfare policies, claiming that they could carry out these measures better and cheaper. But Goldwater's conservatism and his unwillingness to change course to get votes made it difficult for him to make any appeal on welfare matters. As a result, Lyndon Johnson was placed in the unique position of being able to make gains on two issues - prosperity and poverty - even while playing down an aggressive pro-welfare stand in order not to alienate Republicans. And Goldwater spent a good deal of time plaintively arguing that he would not really take social security checks from the pockets of workers when they were not looking.

In the realm of foreign policy, the Democrats were subject to attack as "the party of war" because they happened to be in power during the three major wars of this century. Given Goldwater's proclivity for an adventurous foreign policy, however, a product in part of the style of "stand up and be counted," he could hardly expect to gain votes by appearing to advocate extension of military conflict in South Viet Nam, Berlin, Cuba, and other places. After all, Eisenhower made political capital out of promising "to bring the boys back from Korea," not by promising to send more of them over there. Again, Goldwater was placed on the defensive. $\mathrm{He}$ had the extraordinary task of assuring voters that he would not launch a nuclear war immediately upon assuming office.

If voting behavior theory was correct, as the election returns 
would suggest, Goldwater could not pick up votes on either foreign policy or on the broad spectrum of domestic welfare policy. At the same time, he could not count on full support from normal Republican identifiers and thus had to make repeated calls for party unity. What kind of appeal, then, could he make and to whom?

The answer appeared to be that he could appeal to ordinarily Democratic working class as well as lower-middle-class voters on the racial issue. Hence the many references to safety in the streets and the scarcely veiled suggestions that women would know what he was talking about. Yet this approach also created problems for Goldwater. As a self-professed constitutional conservative, he could hardly call for a federal police force or for most forms of national action except, perhaps, for the appointment of tougher judges. His running mate, William Miller, could suggest that the jobs of workers would be taken by hordes of immigrants who would be let in by new immigration procedures proposed by the Johnson Administration. The trouble was that many of the workers who might have been influenced by this type of appeal came from ethnic groups sensitive to selective limitation of immigration.

A surface reading of the election returns suggests that outside the South the so-called "white backlash" could not have been very large. The workers whose "authoritarian tendencies" presumably left them responsive to a racial appeal, were among the most fervent supporters of the Democratic Party. Racial feelings would have had to be highly salient and intense for them to vote against their traditional party and the social welfare legislation which is so important to them. If a group had felt its jobs threatened, or if it was desperately trying to ward off Negro encroachment on its residential areas, it might be sufficiently moved to change the direction of its vote. But there simply were not enough people in this kind of a position. Apparently, more Republicans were frightened by Goldwater than whites were frightened by Negroes.

On the basis of this analysis, derived from standard voting behavior theory, it was possible to predict long before the election that Goldwater would suffer a drastic defeat. Nor is there any reason to believe that the outcome will be different in 1968 or 1972 so long as the overwhelming purist component of the Goldwater conservatives prevents them from making more successful appeals to the voters. Indeed, immediately after the election Gold- 
water proposed that the parties be organized into pure conservative and liberal denominations. There cannot be much hope for the future when the first reaction of a leader who has suffered overwhelming defeat is to give away to the opposition a substantial percentage of his party's support - the Republican moderates and liberals.

\section{Campaign Morality}

The focus of the campaign upon problems of personal competence was directly connected with the existence of profound differences on public policy. No doubt it was naive to believe that the candidates could differ more and more over issues while saying better and better things about each other. Once Goldwater had moved rather far away from positions traditionally taken by $\mathrm{Re}$ publican presidential candidates, Johnson seized the opportunity to gain Republican votes by denouncing Goldwater as an extremist. The charge of extremism was built into a situation in which any party moved far from where it had been, especially if it also moved far from the voters. It would be easy to say that Goldwater responded to being called an extremist by raising the morality issue or that, lacking appeal on other issues, he used the Bobby Baker episode to undermine Johnson's claim to being defender of the traditional political faith. There may be some truth in this. But I believe that we have more significant answers at our disposal if we turn again to Goldwater and his followers as political purists.

If politics should be concerned with the private conscience of the political leader and his stock of basic principles, as many Goldwater supporters believe, then the morality of the candidates necessarily assumes prime importance. The politician is immediately condemned as immoral by virtue of his usual practices. $\mathrm{He}$ is immoral because he alters his role orientations to suit different constituencies. $\mathrm{He}$ is immoral because, at times, he alters his position to gain votes. Even when the politician hangs on to his fundamental position but gives a little to assure a wider consensus he is immoral because of his inconsistency and vacillation. Because Lyndon Johnson epitomizes the practicing politician, famed for his love of votes, compromise, bargaining, maneuver, and conciliation, his immorality was beyond all dispute for the political purists.

There is still another way in which concentration on political 
style made morality a central focus of election campaigns. The Goldwater purists were patently unwilling to believe that difficulties facing America, particularly in foreign affairs, might have been due to forces beyond the control of any leader. On the contrary, they thought that if the United States just had the right approach, if it stood up for what it believed and enunciated its principles with sufficient force, its problems would be solved. This was presumably what Goldwater meant when he said that he had a "rational solution" to the cold war, without specifying what it was, or when he insisted that our foreign policy difficulties were not complex but simple. If the world situation was not exactly rosy, therefore, the blame lay with immoral leaders who behaved as politicians instead of as purists. They sold out their country because they either did not have the right American principles or did not stand up for them or both. From the Goldwater point of view, it was necessary only to look at the state of the world to see that American political leaders were immoral. Reasoning from effect to cause, the purists would be bound to place the simple moral test - does the candidate have the right political style? at the heart of a campaign taking place when decay had set in from the remotest Asian principality to the nearest city street.

\section{Campaign Issues}

Although the candidates in 1964 were not subject to the kind of abuse characteristic of the early days of the American republic, there apparently was more personal vilification than in the past decade or two. Of greater importance for our purposes, however, is the undoubted fact that in a campaign in which the parties were further apart on issues than they have been in our time, at least since 1936 and possibly in this century, there was relatively little discussion of issues. Certainly, the existence of wide and deep policy differences did not, as has sometimes been thought, lead directly to a campaign focusing on specific issues. Why not?

It might be the case that when candidates are virtually identical in their views, there is little else for them to talk about except their respective personalities. When they are moderately far apart, separated by marginal but real differences, however, the possibility for fruitful debate may be at its highest point. For the parties are then far enough apart to make debates meaningful and yet close enough together so that a real dialogue is possible. Both the can- 
didates and attentive publics can understand what a marginal change from one proposal to another might mean. Yet when the parties and candidates are separated by a huge gulf there may literally be nothing to talk about. The differences may be so severe as to appear to be beyond discussion.

The experience of the 1964 presidential campaign suggests that the old proposition, the greater the differences on issues, the greater the discussion of specific issues, might be replaced with a new hypothesis, discussion of issues varies directly with moderate, marginal disagreements on issues and inversely with the extremes of total agreement or total disagreement. Such has been the situation in France where election campaigns typically involved disagreements among the parties closest to each other and little or no direct confrontation among the parties which were furthest apart in ideology.

\section{Campaign Consistency}

In the light of Goldwater's professed devotion to consistency a major paradox of the campaign was his apparent inconsistency. The syndrome characteristically began with a Goldwater statement about atomic defoliation in South Viet Nam, or giving military commanders control of "conventional" nuclear weapons, or about extremism not being a vice if it is in defense of liberty. In the ensuing furor, Goldwater complained that he had been misquoted or misconstrued; he issued clarifications which puzzled newsmen, and the cycle began again. In other instances, Goldwater maintained consistency; comments that the Tennessee Valley Authority ought to be sold to private interests are not usually made in the heart of the Tennessee Valley. How can we account for this ambivalence?

Goldwater's campaign managers did their best to keep him away from the press; not a single news conference was held during the campaign. One clue may be found in the disparity between the Goldwater supporters and the vast majority of voters. They simply could not believe they were so different from the vast majority of people. Statements unquestioningly accepted by the Senator's most enthusiastic supporters, therefore, occasioned an uproar in the world outside - to the Senator's genuine surprise.

In the final analysis, however, Goldwater's inconsistency may have arisen directly out of his political style. He and his supporters were impatient with the practical substance of policy de- 
cisions. They believed that if the government only approached politics in the right way then everything would be all right. They could hardly be bothered about verbal niceties when they knew in their hearts that their style was fundamentally correct. Traditional politicians may say inconsistent things to gather votes from an electorate which holds inconsistent policy preferences. Goldwater may take inconsistent positions because he is not seriously interested in specific policies.

What, then, have been the major consequences of having a purist candidate on the ballot? Compared to other recent campaigns, 1964 was (1) more bitter; (2) less moral; (3) more concerned with personalities; (4) less concerned with issues; (5) more involved with consistency; (6) less consistent, and (7) for the first time since the Civil War era introduced the explosive question of race relations as a major issue dividing the parties. But these distinctive accomplishments were at least confined to 1964. What will be the future of the party system if purists continue to represent one of the major parties?

\section{The Future}

It has often been said that parties in democratic countries like Great Britain are much more ideological, more strongly divided by serious cleavages over issues, than is the case in the United States. The evidence suggests that this view must be seriously modified. In Great Britain, for example, the political elites of the Labour, Conservative, and Liberal parties are extraordinarily united on domestic policy. They are almost all Keynesians in their economics, pragmatists in their policies on state intervention in the economy, supporters of the welfare state, and fundamentally at peace with the general development of governmental policy in the postwar world. The United States offers a striking contrast: a conservative political elite, disproportionately located in the Republican Party, regards Keynesian economics as a dirty word, views governmental activity in the economy with ideological hostility, and is reconciled neither to the future growth of the welfare state nor to its steady development over the past 30 years. While not all political leaders in Great Britain are satisfied with its foreign policy, the impression is that most are agreed on essentials. There is no equivalent of the increasing frustration the Republican conservatives feel because the superior resources of the United 
States do not confer an automatic ability to control events beyond its borders. Of course, some Democrats share these feelings, but they cannot prevail within their national party.

This is not the place to argue about which views are correct or more nearly in tune with the realities of our time. But it is the place to say that the existence of a political elite, in a position to control a major national party, which holds views widely at variance both with the general voting population and its own followers, presents a major political problem in the United States. Goldwater's nomination and defeat are merely a sign of an old problem, but one hidden by the normal operation of the party system. What are some of the consequences for American political parties?

One possibility is that the Republican Party will return to its previous course and seek out popular candidates whose moderate views will give it a chance to win presidential elections. Once it is understood, however, that the Goldwater movement is not a temporary aberration, but represents a profound current within the Republican Party, it becomes impossible for me to join the wishful thinkers who believe that the moderates and liberals in the party will automatically gain control after Goldwater's severe defeat in the election. A majority of party activists now support the political tendency Goldwater represented. (It might be well to recall that an Associated Press poll of Republican county chairmen, taken in April, 1964, showed that 722 chose Goldwater as their personal preference compared to 301 for Nixon.) If these conservatives are to be defeated they will have to be challenged by a rival, moderate elite, willing to engage in the daily tasks of political organization over the next four years. No one has been able to tell where these people will come from, especially after the Republican Party has been swept out of office at all levels in a Johnson landslide.

The possibility cannot be ruled out that the Republican Party will continue to nominate conservatives like Goldwater and will continue to lose badly. I believe that those who see in this development the likelihood of a realignment of the major parties along conservative and liberal lines will be grievously disappointed. What incentive would there be for conservative Democrats from the South to join a lost cause? On the contrary, they would more than ever be impelled to cling to the Democratic affiliation which 
at least promises them continued influence in Congress and some chance to modify the policies of Democratic Presidents. Republican moderates and liberals, however, might find association with the prevailing centers of power in the Democratic Party more and more attractive.

In a study of state party systems, the late V. O. Key, Jr., has shown that as one party dominates the political scene by gaining continual electoral victories, nomination becomes tantamount to election; and there is a strong tendency for voters to move into the primaries of this party in order to gain some influence over its decisions. The minority party loses its moderates and becomes the preserve of the "diehards." Hence it becomes increasingly difficult for a candidate who might appeal to the electorate to win nomination in the minority party. Nor are the consequences for the majority party necessarily good. As it grows in relative size and importance it becomes more heterogeneous. At the same time the weakness of the opposition removes a powerful incentive to party cohesion.

Should this vision of the future materialize, we can expect an end to a competitive, two-party system. In its place we will have a modified one-party system with a dominant Democratic Party. As its leaders find that their potential for controlling policy decisions has enormously increased they will also discover that greatly intensified factionalism within the party has strikingly diminished their capacity for united action. The immediate policy goals of an accelerated welfare state - medical care for the aged, aid to education, antipoverty programs - may be achieved ahead of schedule as a result of extraordinary Democratic Party majorities in Congress. But these victories for liberal Democrats may be achieved at the price of inability to meet new problems. For the more overwhelming the dominance of their party, the less may be their importance within it. The success of liberal ideas will have been sacrificed to the triumph of their party. The Republican Party, much diminished in size, will find that its greater potential for unity is accompanied by a drastically reduced capacity to get its preferences translated into government policy. It will have gained cohesion in exchange for impotence. The 1964 election may turn out to be a disaster for conservative Republicans and a Pyrrhic victory for liberal Democrats.

There has been a great deal of loose talk in the past about 
the desirability of having an avowed conservative run for the presidency on the grounds that a severe defeat would put his backers "in their place" and demonstrate once and for all that they lack support in the country. The Goldwater candidacy, however, visibly increased the cost of losing the election to those who disagreed profoundly with him. As a result, there was a much more bitter campaign fraught with much greater anxiety than in the past. Will the comforts of a political system which is ordinarily kind to losers (because campaigns are fought between parties and candidates which differ somewhat but are not separated by too large a gulf) be more highly valued in the future? That depends on whether the rest of us learn the lessons which the Goldwater phenomenon has to teach us.

It is possible that the Goldwater phenomenon represents the beginnings of ideology in the United States. Although markedly different in their policy preferences, there are segments of the left as well as the right who are repelled by the usual patterns of democratic politics. There appears to be little difference in style between the Goldwater purists and the leftists who constantly complain about hypocrisy in public life and how the politicians sell out the people. Could it be that the United States is producing large numbers of half-educated people with college degrees who have learned that participation (passion and commitment) is good but who do not understand (or cannot stand) the normal practices of democratic politics? If this is true, we shall be hearing a great deal more from those who identify compromise with moral degeneracy. Political scientists might then wish to present their knowledge about the consequences of political purism. They might also wish to impart some wisdom on the relative desirability of flexible and inflexible political styles under varying conditions. For the Goldwater phenomenon, which once seemed so strange, may become a persistent feature of the American political scene, nonetheless disturbing because it reappears under different ideological guises. 